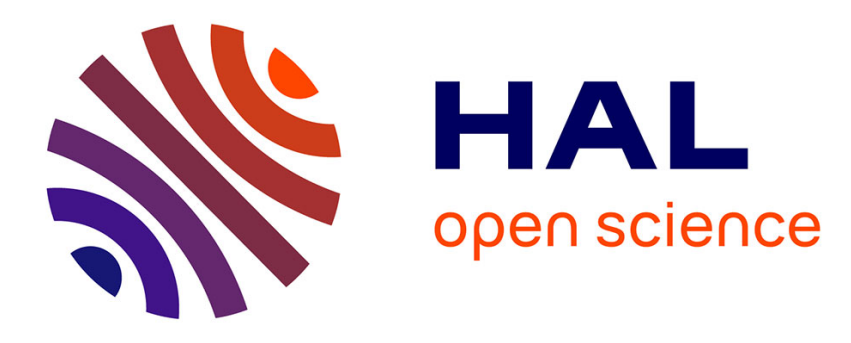

\title{
Pollen load composition and size in the leafcutting bee Megachile rotundata (Hymenoptera: Megachilidae)
}

\author{
Ruth O'Neill, Kevin O'Neill
}

\section{To cite this version:}

Ruth O'Neill, Kevin O'Neill. Pollen load composition and size in the leafcutting bee Megachile rotundata (Hymenoptera: Megachilidae). Apidologie, 2011, 42 (2), pp.223-233. 10.1051/apido/2010057. hal-01003592

\section{HAL Id: hal-01003592 \\ https://hal.science/hal-01003592}

Submitted on 1 Jan 2011

HAL is a multi-disciplinary open access archive for the deposit and dissemination of scientific research documents, whether they are published or not. The documents may come from teaching and research institutions in France or abroad, or from public or private research centers.
L'archive ouverte pluridisciplinaire HAL, est destinée au dépôt et à la diffusion de documents scientifiques de niveau recherche, publiés ou non, émanant des établissements d'enseignement et de recherche français ou étrangers, des laboratoires publics ou privés. 


\title{
Pollen load composition and size in the leafcutting bee Megachile rotundata (Hymenoptera: Megachilidae)*
}

\author{
Ruth P. O’NeILL ${ }^{1}$, Kevin M. O’NEILL ${ }^{2}$ \\ ${ }^{1}$ Department of Animal and Range Sciences and Department of Plant Sciences and Plant Pathology, \\ Montana State University, Bozeman, MT 59717, USA \\ ${ }^{2}$ Department of Land Resources and Environmental Sciences, Montana State University, Bozeman, MT, USA
}

Received 31 December 2009 - Revised 7 May 2010 - Accepted 10 May 2010

\begin{abstract}
We examined how the species composition and volumes of pollen loads of Megachile rotundata varied seasonally and among females of different body sizes. Alfalfa and mustards (Brassicaceae) made up, on average, $88-95 \%$ of the pollen load volumes in each of three seasonal samples; in total, the 300 females sampled carried ten different pollen types. Because of variation in pollen grain size among plant species, estimates of the contribution of different species to pollen loads, based on pollen counts only, differed from those adjusted for pollen grain size. The overall size of pollen loads, as well as the contribution of alfalfa declined seasonally, while that for mustards (with smaller individual grain sizes) increased. The type of pollen carried by females did not vary with body size, but we found a significant relationship between female size and the size of the largest loads. Surprisingly, females of intermediate size carried the largest pollen loads, whether measured by counts or volume.
\end{abstract}

\section{Megachile rotundata / alfalfa / pollen load composition / seasonal variation / body size}

\section{INTRODUCTION}

The alfalfa leafcutting bee, Megachile rotundata L. is used widely in western North America as a managed pollinator of seed alfalfa (lucerne, Medicago sativa L.) (Pitts-Singer, 2008). Females are solitary nestprovisioners that, in managed populations, nest in dense aggregations in alfalfa fields within artificial "bee shelters". The shelters contain large arrays of closely-spaced nest tunnels within polystyrene or wood blocks. Though valuable as an alfalfa pollinator, females collect pollen from a wide range of flowering species, both in confined experimental conditions (Horne, 1995; Small et al., 1997) and within seed alfalfa fields (Jensen et al., 2003; O'Neill et al., 2004). Data on

Corresponding author: K.M. O’Neill, koneill@montana.edu

* Manuscript editor: Stan Schneider the species composition and size of pollen loads carried by female solitary bees can provide answers to various of questions regarding the foraging behavior and ecology of bees. One question relates to their effectiveness as pollinators, which is partly reflected in the composition and purity of their pollen loads (Ne'eman et al., 1999). Another set of questions concerns the foraging behavior of bees: by determining the frequency distribution of pollen types present on females, one can assess resource utilization and, under some conditions, foraging ranges (Beil et al., 2008). Assessment of pollen loads can also be used in studies of parental investment: by evaluating the size and nutritional value of pollen loads, one can examine the fitness costs and benefits associated with different foraging tactics, body sizes, and resource types (Neff, 2008).

Our previous studies of the pollen loads $M$. rotundata focused on how the relative abundances of alternative pollen sources in the 
vicinity of nests affected pollen resource use (O'Neill et al., 2004). In that study, we estimated the relative frequencies of different plant species from subsamples of individual pollen loads collected at two times during the nesting season (July and August). Here, we report on a study at the same site in which we estimated the absolute number of pollen grains of different plant species carried by females, calculated the volume of pollen loads based on measurements of individual pollen grains, and extended the analysis later into the nesting season (September). One objective was to compare assessments obtained by simply counting pollen with estimates of the contribution of each pollen type to the total volume of the pollen load, an approach advocated by O'Rourke and Buchmann (1991) and Cane and Sipes (2006). We also examined the relationship between female body size and the sizes of their pollen loads. Finally, we use published values for protein and lipid content of the two major pollen types to estimate their relative contributions to the nutritive value of pollen provisions.

\section{MATERIALS AND METHODS}

Bees for pollen load analysis were collected on a commercial irrigated seed alfalfa farm near Toston, Broadwater Co., Montana in 2004. On each of three dates (30 July, 13 August, and 2 September), at each of 10 nest shelters, we collected 10 females as they returned to nests. The field was not harvested until after our last sample was taken. We collected females as they returned to nest, but unlike in our previous study (O'Neill et al., 2004), we did not deliberately collect just females with visible pollen loads on their abdominal scopae. We did, however, avoid collecting females that were carrying leaf pieces, as we assumed that they were not returning from provisioning trips. To prevent pollen loss and cross-contamination that might occur if females were collected in nets, they were trapped directly into $1.5 \mathrm{~mL}$ Eppendorf tubes when they landed on nest board surfaces.

Later, we extracted pollen from each female by filling the Eppendorf tube with $70 \%$ ethanol and placing the tube in a sonicating water bath for 5$10 \mathrm{~min}$. The female was removed and the tube was centrifuged at $4000 \mathrm{rpm}$ for $5 \mathrm{~min}$, after which the ethanol was decanted and replaced with a solution of safranin stain; the tube was then agitated with a vortex to resuspend the pollen. After $24 \mathrm{~h}$ and another centrifugation, we decanted the stain and added $20 \mu \mathrm{L}$ of distilled water, before resuspending the pollen.

To identify and count the pollen, a subsample of the suspension was pipetted onto a hemacytometer under a cover slip. Then, at $10 \times$ power under a compound microscope, we counted the number of grains of each pollen type in the four larger corner squares of the hemacytometer; we switched to higher magnification only to aid in identification. We then calculated the total number of pollen grains per $\mu \mathrm{L}$ of the subsample and multiplied that by the total volume of the suspension to determine the total number of pollen grains extracted from each female. The resulting value is a minimum estimate, as our extraction technique cannot be considered to be $100 \%$ effective; when the scopae of females were examined after pollen extraction, pollen grains of different sizes were still present, but our technique did remove the vast majority of grains from females carrying full pollen loads. Pollen was identified using comparisons to reference slides prepared from flowers collected at the research site. The ten pollen types recognized included Canada thistle (Cirsium arvense $\mathrm{L}$. (Scop.)), sow thistle (Sonchus sp.) spotted knapweed (Centaurea maculosa L.) (Asteraceae), lambsquarters (Chenopodium album L.), kochia (Kochia scoparia (L.) Schrad.) (Chenopodaceae), alfalfa, yellow sweetclover (Melilotus officinalis (L.) Lam.) (Fabaceae), mullein (Verbascum thapsus L.) (Scrophulariaceae), mustard (Brassicaceae), and one unknown type. Most Brassicaceae pollen was probably from Brassica sp., though some may have been from Sisymbrium altissimum L., as we observed bees foraging on both plants.

To estimate pollen grain volume, we measured the dimension of 20 pollen grains of each species on the reference slide using an ocular micrometer. Pollens of seven of the 10 pollen categories were treated as spherical, with volume $=4 / 3(\pi)\left(r^{3}\right)$, where $r=$ radius. The three others, alfalfa, sweetclover, and mustard, were prolate spheroids with volume $=4 / 3(\pi)\left(a^{2}\right)(b)$, where $a=$ equatorial radius and $b=$ polar radius. (Note that our estimates for the volume of alfalfa pollen grains are lower than two published estimates (Kapp et al., 2000; Müller et al., 2006). The differences could perhaps be due to differences in sample preparation among studies, which can affect pollen size (Kapp et al., 2000) 
or to intraspecific variation in pollen grain volume between cultivars of alfalfa (Karise et al., 2006). Whatever the reason, the differences probably do not affect our main conclusions, because we treated pollen of all species identically and all of our comparisons are relative.) Once individual grain volumes were determined, we calculated pollen load volume by multiplying grain volume by the total number of pollen grains of each type and summing the values for all pollen types on a female; the resulting value is the total volume of grains provided to offspring from that pollen load, not the volume of the load (including spaces between pollen grains) as it sat on the scopa. Head widths of all female bees collected for pollen analysis were measured to the nearest $0.01 \mathrm{~mm}$ using a microscope equipped with an ocular micrometer

All means are presented \pm standard errors. Multiple comparisons were made with KruskalWallis tests, with Student-Newman-Keuls tests used for pairwise comparisons $(\alpha=0.05)$. Linear and polynomial regressions were conducted using SigmaStat ${ }^{\complement}$. Plant species diversity in pollen loads was characterized using Hill's \#2 diversity index, the effective number of very abundant species in a sample (Ludwig and Reynolds, 1988). The index, which is the inverse of the commonly used Simpson's Index, has a low sensitivity to small sample sizes, and ranges upward from a value of 0 , which would occur for a sample with a single species.

\section{RESULTS}

\subsection{Assessment of pollen loads based on pollen grain counts}

For all 300 females collected, the predominant pollen types by count were alfalfa (52\% of all pollen grains), mustard (42\%), and sweetclover (4\%) (Tab. I, Fig. 1). The total number of grains per female did not vary among the three sampling periods (Tab. II). Alfalfa pollen counts, however, declined from July to September, whereas those for mustard increased dramatically in August and remained high in September, exceeding alfalfa counts in both of the latter months. Alfalfa pollen was present on all 300 females examined, mustard on $79 \%$, sweetclover on $32 \%$. The relatively high value for lambsquarters in July was due to a large load extracted from a single female that carried $99 \%$ of all lambsquarters pollen recorded during the study; only 4 females carried lambsquarters pollen in the July sample, and just 11 overall. Mullein was the rarest pollen type, being found on just two females, and in each case represented less than $1 \%$ of the pollen on those females.

Among the 300 females, 107 had estimated pollen loads exceeding 100000 grains, while the number exceeding 100000 of a single type was 37 females for alfalfa, 43 for mustard, 5 for sweetclover, and 1 for lambsquarters. If we take the strictest definition of a pure pollen load as $100 \%$ of one type, 37 females carried pure loads, all alfalfa, ranging in size from 92 to over 124000 grains. However, even a female that visits just one flower type during a foraging trip would likely carry some pollen from previous trips or from picking up pollen during nectar gathering visits to flowers. If we take a less restrictive, but still conservative cutoff value of $98 \%$ of one pollen type, 76 females carried pure alfalfa loads and 2 pure mustard loads. With a cut-off of $95 \%$, the numbers were 98 for alfalfa and 9 for mustard. The only values exceeding $10 \%$ for other species included 32 for sweetclover (maximum $=94 \%$ ), 6 for Canada thistle (58\%), 5 for sow thistle (78\%), 3 for spotted knapweed (19\%), and 1 each for lambsquarters $(88 \%)$, kochia $(11 \%)$, and the unknown species (14\%). The maximum number of pollen types per female was five, observed on eight females.

Using Hill's \#2 index, pollen load diversity was lower in July (mean $=1.24 \pm 0.05)$ than in either August (mean $=1.54 \pm 0.05)$ or September $($ mean $=1.52 \pm 0.04)$ (KruskalWallis test, $P<0.001 ;$ S-N-K test, July $<$ August $=$ September). This corresponds to the higher number of $100 \%$ pure alfalfa loads in July (27) than in either August (5) or September (5).

\subsection{Assessment of pollen based on pollen grain volume}

The ten pollen types varied widely in the size of individual grains (Fig. 2), with the largest (kochia) having $>30$ times the estimated volume of the smallest (mustard) and 

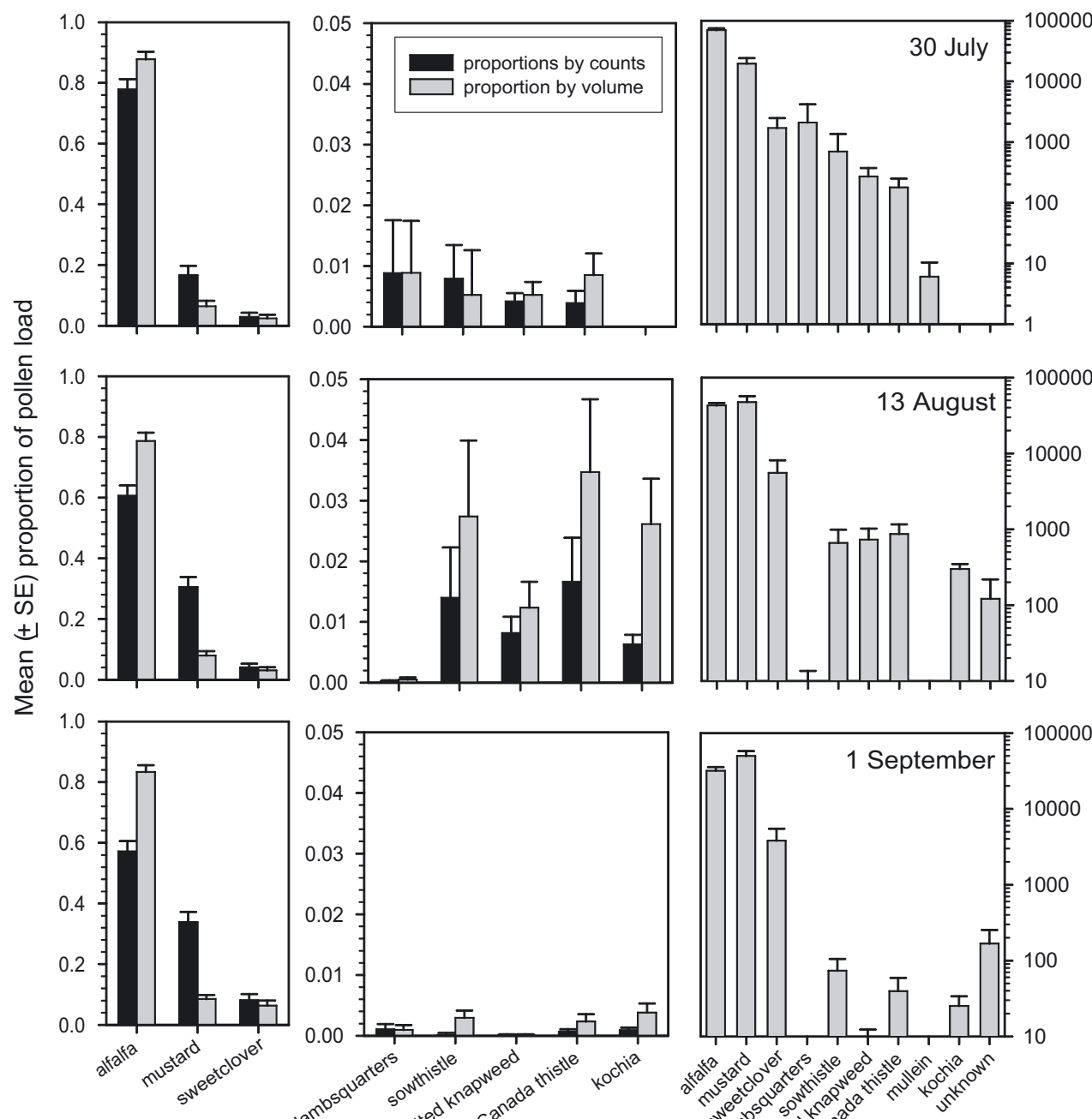

Figure 1. Left and center: mean proportions of pollen load comprised of each plant taxon, comparing proportion by pollen grain count to proportions by pollen load volume. Note difference in scale between two columns. Right: frequency distribution of total pollen load counts $\left(\log _{10}\right.$ scale) for each plant taxon.

with alfalfa pollen being in the middle of the size distribution. Pollen load volume was significantly related to total pollen grain count (linear regression, $\mathrm{r}^{2}=0.31, \mathrm{~F}_{1,298}=131.2$, $P<0.001$; Fig. 3), but the relationship was better modeled with a polynomial regression $\left(\mathrm{r}^{2}=0.50, \mathrm{~F}_{1,298}=150.2, P<0.001\right)$, where volume peaked at about 250000 grains per load. In general, pollen loads dominated by mustard (by count) were among those with the smallest total volumes. No pollen load consisting of $\geqslant 75 \%$ mustard was in the upper half of the range of load volumes. In contrast, 14 of the 18 loads (by volume) in the upper half of the range consisted of $\geqslant 75 \%$ alfalfa (by counts).

Although total pollen counts did not vary among the three samples, pollen load volume declined from July to September (Tab. II). The major reason is that, as alfalfa counts declined, those for Brassicaceae increased. Although this was partially compensated for in 

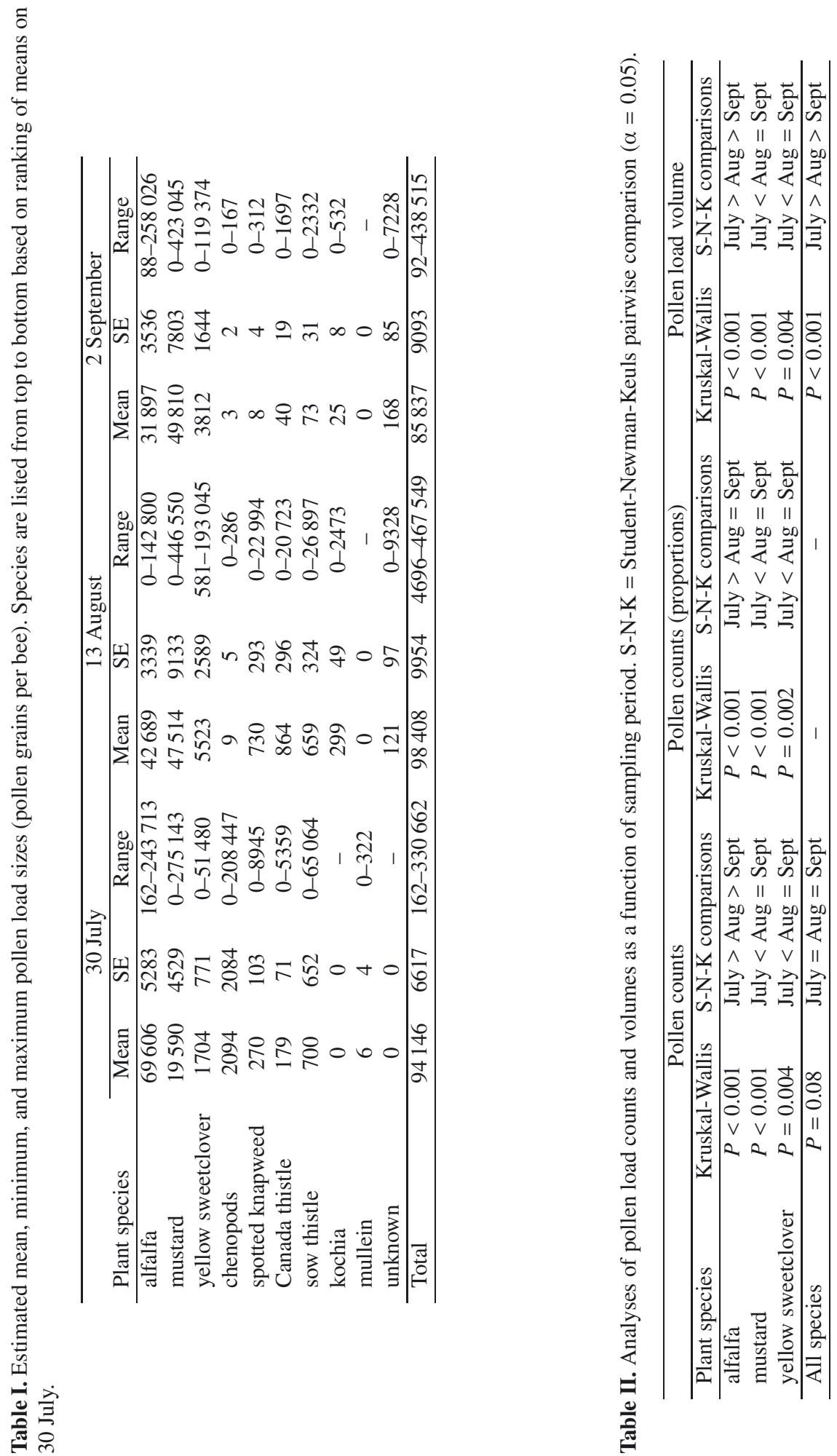


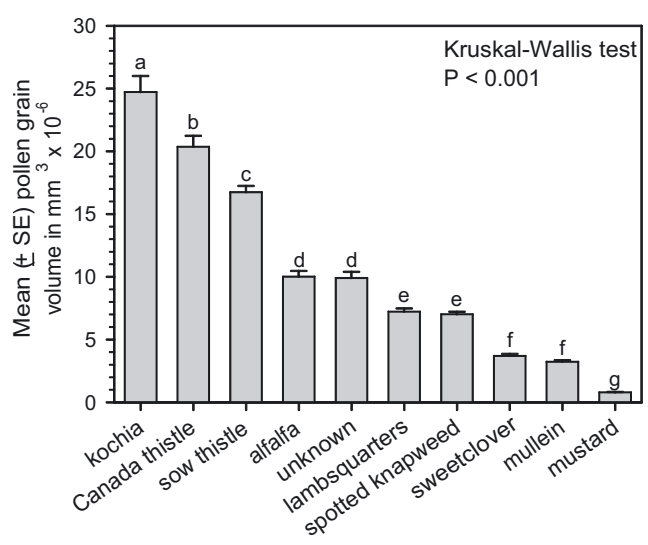

Figure 2. Mean estimated volumes of individual pollen grains for each of ten pollen types $(\mathrm{N}=20$ for each type). Means followed by different letters have significantly different pollen sizes (StudentNewman-Keuls test).

August by the increased numbers of grains of larger pollen types (sow thistle, Canada thistle, and kochia), they constituted too small a proportion of pollen loads to compensate for the greater use of mustards. Thus, assuming that load volume is a superior measure of the relative contribution of a pollen type to the provisions of $M$. rotundata, pollen counts underestimate that contribution for alfalfa, sow thistle, spotted knapweed, Canada thistle, and kochia, whereas they overestimate it for mustards. Although this conclusion is specific for the site at which we worked, the data do suggest that caution must be taken when drawing conclusions about pollen loads that are based solely on pollen counts (see also O'Rourke and Buchmann, 1991; Cane and Sipes, 2006).

\subsection{Female body size and pollen load metrics}

There was a non-linear relationship between head width and total pollen count for all females (Fig. 4, top), but the relationship was weak, with head width explaining only about $3 \%$ of the variation in pollen counts. However, females in this analysis very likely included many that were not returning from pollenforaging trips and some that were returning from relatively unsuccessful trips. Thus, to get a better estimate of how maximum pollencarrying capacity varies with body size, we repeated the analysis using only the females in each size category with the largest recorded total pollen load counts (Fig. 4, middle) and largest load volumes (Fig. 4, bottom). In those analyses head width explained $19 \%$ of the variation in total counts and $35 \%$ of the variation in load volume. Pollen load counts and volumes peaked at the same head width value of $\sim 3.2 \mathrm{~mm}$ in the two analyses, slightly above the middle of the size distribution of females examined.

Female body size appears to be unrelated to the types of pollen gathered. The mean size of females whose pollen loads consisted of $\geqslant 90 \%$ alfalfa (mean $=3.19 \pm 0.01 ; \mathrm{N}=126)$ did not differ from those whose loads consisted of $\geqslant 90 \%$ mustard (mean $=3.17 \pm 0.03 ; \mathrm{N}=$ 21) (t-test, 145 d.f., $t=0.536, P=0.59$ ). Similarly, the mean size of females whose pollen loads consisted of $\geqslant 75 \%$ alfalfa (mean $=3.19 \pm 0.01 ; \mathrm{N}=159$ ) did not differ from those whose loads consisted of $\geqslant 75 \%$ mustard (mean $=3.16 \pm 0.03 ; \mathrm{N}=39$ ) ( $t$-test, 196 d.f., $t=0.1 .18, P=0.24)$. Head width was also uncorrelated with the diversity of pollens carried (Hill's \#2 diversity index; Spearmann rank correlation, $\mathrm{r}=-0.02, P=0.72$ ).

\section{DISCUSSION}

Alfalfa leafcutting bees in the commercially-managed population we studied nested within or adjacent to a large irrigated monoculture of alfalfa that harbored lower densities of mustard, sow thistle, and Canada thistle. In addition, the non-irrigated, non-cultivated weedy area surrounding the field contained patches of kochia, spotted knapweed, and sweetclover on which bees foraged.

Reflecting their value as commercial alfalfa pollinators (Pitts-Singer, 2008), all M. rotundata females sampled carried alfalfa pollen. But alfalfa comprised barely over $50 \%$ of the pollen grains extracted from bees in the overall sample, and $<40 \%$ in the September sample. The decline in the use of alfalfa during the season and the consequent greater use of 


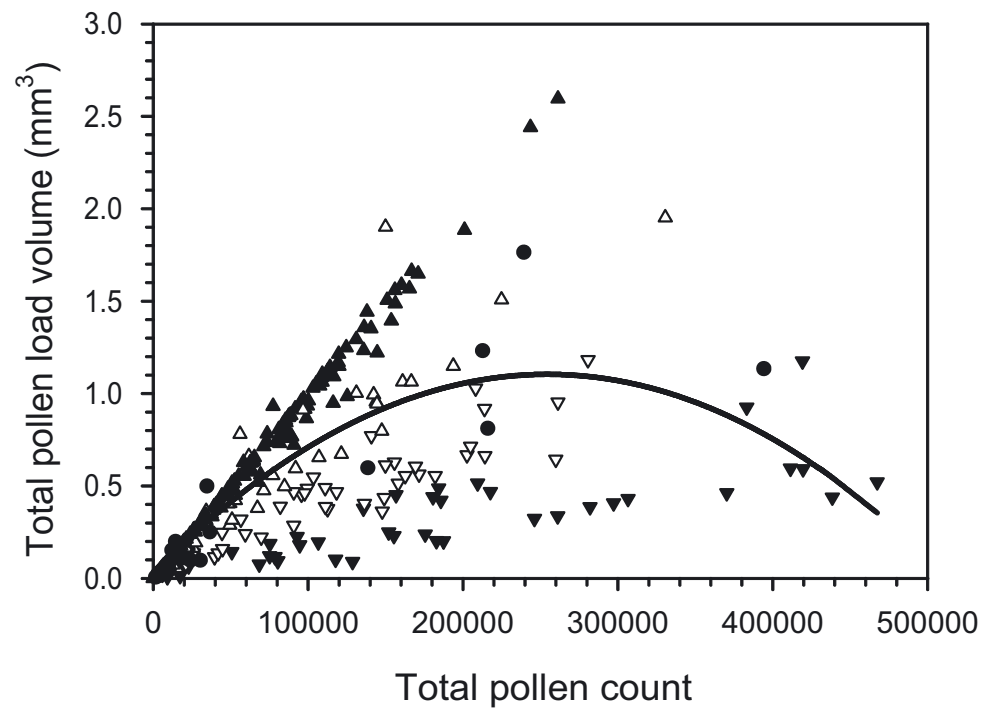

Figure 3. Relationship between total pollen load volume and count for all pollen loads examined. Symbols: closed triangle $=$ loads where alfalfa exceeded $75 \%$ of total; open triangle $=50-75 \%$ alfalfa; closed inverted triangle $=75-100 \%$ mustard ; open inverted triangles $=50-75 \%$ mustard; closed circles $=$ all other pollen loads. Polynomial regression: $\mathrm{y}=0.0338+0.00000841 \mathrm{x}-0.00000000001652 \mathrm{x}^{2}$.

other plant species, especially Brassicaceae, was likely due to a decline in the availability of untripped alfalfa flowers as the season progressed. The relative densities of these and other flowering plants at the same site was assessed in an earlier study, in which we showed that the proportion of pollen types extracted from females correlated with the relative density of different plant species within $50 \mathrm{~m}$ of nest boxes (O'Neill et al., 2004). The "tripping" mechanism by which pollen is released by an alfalfa flower is well-known (McGregor, 1976). When a bee lands on a flower and attempts to feed, it causes the keel petal to separate and release the sexual column, which springs upwards, strikes the bee, and dusts it with pollen; tripping is irreversible, so one can recognize a tripped flower by the readily visible sexual column. Once an alfalfa flower is tripped by the visit of a single bee, its value to other bees declines. Strickler and Freitas (1999) showed that the number of untripped alfalfa flowers available to bees in commercial seed fields pollinated by $M$. rotundata declined exponentially during a season. Four weeks after adult $M$. rotundata were released into their fields, the mean number of open flowers per raceme was about half that available two weeks after release. And after eight weeks, a time that would correspond approximately our September sample, the number had declined to about $10 \%$.

The mean percentages of alfalfa pollen (57$78 \%$ ) in the three samples in this study were lower than in the two samples in our previous (2002) study at the same site (82-94\%) (O'Neill et al., 2004). In addition, the contribution of mustards was higher in 2004 (17-34\%) than in 2002 (6-8\%). Although some of the differences between the two years may be due to different analytical techniques, it may also be that plant diversity changed if weed abundance and diversity increased in 2004. The alfalfa field is adjacent to non-cultivated land that, in 2004, harbored high weed diversity and larger patches of flowering knapweed and sweetclover, some of which were within several meters of nest shelters. In 2002, when we sampled only in July and August, $4 \%$ of the females carried knapweed and $10 \%$ sweetclover. In 2004, the values (July and August only) were $22 \%$ for knapweed and $28 \%$ for sweetclover. 

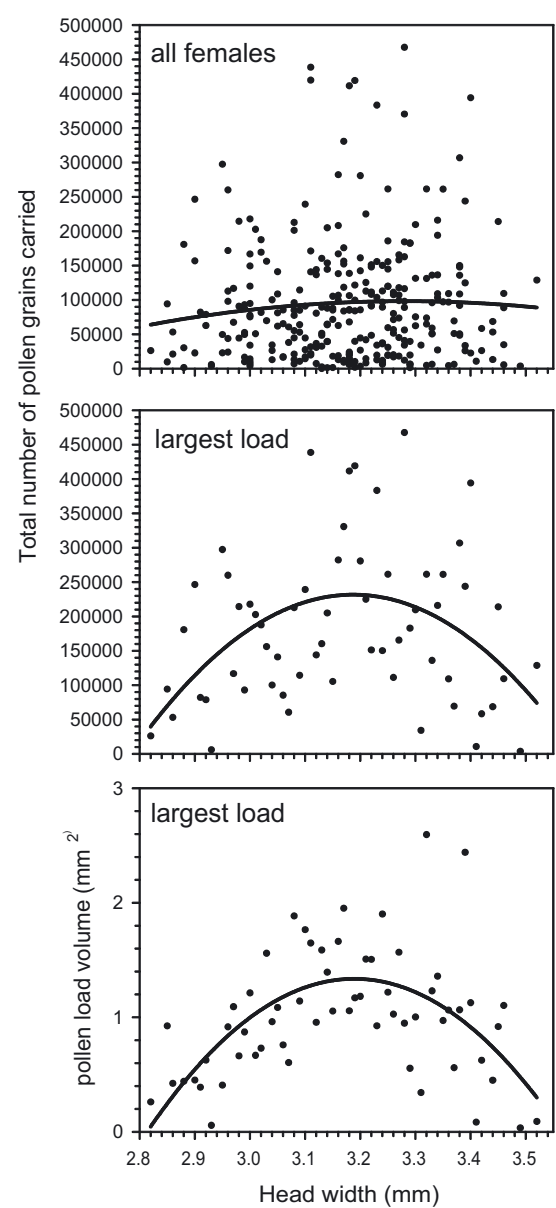

Figure 4. Relationships of head width to total pollen load counts for all females (top) (count $=$ $-2058477+($ head width $* 1294965)-\left(\right.$ head width ${ }^{2}$ * 198481; $\left.\mathrm{F}_{1,298}=4.23, \mathrm{r}^{2}=0.03, P=0.04\right)$, for females in each $0.01 \mathrm{~mm}$ size category with the largest recorded pollen load counts (count $=$ $-14229832+($ head width $* 9074259)-($ head width $\left.^{2} * 1423472 ; \mathrm{F}_{1,59}=6.61, \mathrm{r}^{2}=0.19, P=0.04\right)$, and for females in each $0.01 \mathrm{~mm}$ size category with the largest recorded pollen load volumes (volume $=$ $-95.017+($ head width $* 60.424)-\left(\right.$ head width $^{2}$ * 9.473; $\left.\mathrm{F}_{1,59} 15.53, \mathrm{r}^{2}=0.35 ; P<0.001\right)$.

Several previous studies have also addressed the fact that interspecific variation in pollen grain size results in pollen load counts and volumes providing different pictures of the contribution of alternative pollen types to provisions. In a study of honey bees in Arizona, for example, O'Rourke and Buchmann (1991) found that the use of pollen grain counts underestimated the contribution of some species to total pollen load volume in those species with large pollen grains, such as Whitehorn acacia (Acacia constricta Benth.), Yucca (Yucca harrimaniae Trel.), and Giant saguaro (Cereus giganteus Engelm. Britton and Rose). The contribution of Eucalyptus sp. to pollen provisions, in contrast, was greatly overestimated using counts. Similarly, in an analysis of pollen collected by the solitary bee Diadasia diminuta (Cresson) (Sipes, 2001), Asteraceae contributed $14 \%$ of pollen grains to loads, but made up only $4 \%$ of the load by volume. However, the importance of Cactaceae was underestimated by over three-fold $(<1 \%$ vs. $3 \%)$, unless pollen grain volume was considered.

In our study, as the bees switched to alternative pollen sources in August and September, the number of pollen grains carried by females remained about the same, but pollen load volume declined. Apparently, bees did not compensate for lower alfalfa pollen availability later in the season by lengthening the duration of foraging bouts to keep pollen load sizes as large as they were in July (though it is certainly possible that they increase the number of foraging trips per cell provisioned). But the observed seasonal changes in pollen load sizes could have less consequence for bees if they were able to collect higher quality pollen late in the summer. Although we did not assess the nutritional quality of alternative pollen types in this study, published values exist for the protein and lipid content of alfalfa and mustards, which made up on average, $88-95 \%$ of the pollen load volumes in each sample. For crude protein content, Stace (1996) gives values of $20-24 \%$ for alfalfa pollen, whereas for three Brassica species, Roulston and Cane (2000) cite values of 32-44\%. Conservatively taking the minimum proportion protein for alfalfa (0.20) and the maximum value for Brassica (0.44) and multiplying those by the mean volumes of loads composed of alfalfa and mustard, the total protein content of pollen loads declined during the summer, despite the greater use of Brassica (Fig. 5). Relative to July, estimated protein content of pollen loads declined by at least 31\% in August and 46\% 


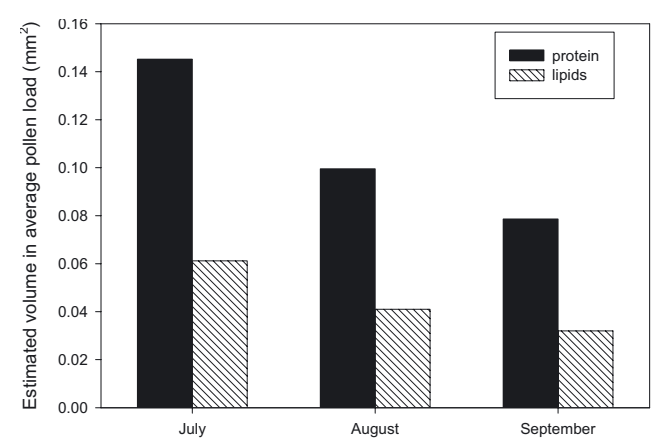

Figure 5. Estimated pollen and lipid contents of average-sized pollen loads (due to alfalfa and mustards), based on our estimates of volume of loads comprised of alfalfa and mustard and published values for protein and lipid contents of pollen (see text for explanation).

in September. The results are similar when estimating lipid content of pollen using values cited by Roulston and Cane (2002), 8.5\% for alfalfa and 9.9-14.5\% for three species of Brassica. Using the $8.5 \%$ for alfalfa and $14.5 \%$ for Brassica, lipid content of pollen loads declined on average (relative to July) by at least $33 \%$ in August and 48\% in September. Based on these estimates, it appears that as females at our study site switched pollen types late in the season, the potentially higher protein and lipid content of the new dominant pollen type did not compensate for the smaller pollen loads carried.

The pollen loads carried by bees may not impose the same type of load-carrying constraint experienced by nest-provisioning solitary wasps, some of which carry prey that are heavy relative to their own weights (e.g., Coehlo, 1997). As a result one often finds a positive linear correlation between female size and prey size in solitary wasps (reviewed in O’Neill, 2001). Klostermeyer et al. (1973) estimated that the total average provision load mass carried by female $M$. rotundata on a foraging trip (nectar and pollen, combined) was $12-13 \%$ of body mass; this value is in the lower part of the range observed among bee species (Neff, 2008). For honey bees, although there is some evidence that larger foragers carry heavier loads, pollen loads that increased total mass (bee mass + load mass) by up to $40 \%$ had a relatively small effect on metabolic rate of hovering bees $(6 \%)$ (Feuerbacher et al., 2003). In addition, the fact that sexual size dimorphism is lower in bees compared to apoid wasps suggested to Shreeves and Field (2008) that there is weaker selection in female bees for body size related to load-carrying capacity. Nevertheless, the assumption that larger $M$. rotundata have larger abdominal scopae led us to expect that we would find a positive linear correlation between female body size and pollen load size. Thus, the non-linear relationship that we found (for maximum pollen load capacity) is somewhat puzzling. One possibility is that the density of scopal hairs or some other aspect of the morphology of scopae varies among females of different size, with intermediate-size females being able to pack greater numbers of pollen grains into their scopae than either smaller or larger females. Another possibility is that some factor that affects foraging efficiency (e.g., flight speed, foraging range, or pollen handling time) also varies with body size, with peak performance being at intermediate body sizes. Regardless of the mechanism, the body size-pollen load size relationship needs to be further explored for M. rotundata.

\section{ACKNOWLEDGEMENTS}

We thank Thomas Helms for allowing use of his alfalfa fields and bees, and Jessica Fultz for advice on pollen analysis. Our research was supported with funds from USDA-ARS Bee Biology and Systematics Laboratory, the Northwest Alfalfa Seed Growers Association, the Montana Alfalfa Seed Growers Association, the Montana Department of Agriculture, and the Montana State University Agricultural Experiment Station.

Composition et taille de la pelote de pollen chez la mégachile de la luzerne Megachile rotunda (Hymenoptera : Megachilidae).

Megachile rotunda / luzerne / pelote de pollen / composition / taille corporelle / variation saisonnière 
Zusammenfassung - Zussamensetzung der Pollenladungen und Größe der Blattschneiderbiene Megachile rotundata. (Hymenoptera: Megachilidae). Die Alfalfa-Blattschneiderbiene Megachile rotundata wird im westlichen Nordamerika weitverbreitet als Bestäuber im Alfalfa-Anbau (Luzerne) gehalten. Die Weibchen sind solitäre Nister, für deren Haltung in dichten Aggregationen seitens der Alfalfa-Pflanzer künstliche Bienenstände bereitgestellt werden. Diese Stände bestehen aus großen Einheiten dichtgepackter Niströhren in Polystyrol- oder Holzblöcken. Obwohl sie vor allem für die Alfalfa-Bestäubung von wirtschaftlicher Bedeutung sind, sammeln die Weibchen von einem breiten Pflanzenspektrum Pollen für die Anlage der Brutzellen.

Anhand von Pollenproben, die von Bienen in drei Sammelperioden innerhalb eines Alfalfafelds stammten, in dessen Umgebung auch andere Pflanzen blühten, ermittelten wir die Zahl der Pollenkörner verschiedener Pflanzen und berechneten das Volumen der jeweiligen Pollenladungen basierend auf den Messungen der einzelnen Pollenkörner. Bei allen der 300 untersuchten Bienen war Alfalfa mit $52 \%$ aller Pollenkörner der dominante Pollentyp, gefolgt von Senf (42\%) und Süssklee (4\%). Insgesamt trugen die Bienen zehn unterschiedliche Pollentypen von mindestens fünf verschiedenen Pflanzenfamilien ein (Tab. I, Abb. 1). Nach Korrektur der Daten bezüglich der Schwankungen im Pollenkornvolumen lagen die Mitttelwerte für Alfalfa und Senf zusammen bei 88-95 \% der Volumina der Pollenladungen in jeder der drei Sammelperioden.

Aufgrund der Schwankungen in der PollenkorngröBe der verschiedenen Pflanzenzarten (Abb. 2) wichen die Schätzungen der auf Pollenzahlen beruhenden Beiträge der verschiedenen Pflanzen für die Pollenladungen von denen der in Bezug auf die Pollengröße korrigierten Werte ab (Abb. 1 und 3). Die Gesamtgröße der Pollenladungen wie auch der Beitrag von Alfalfa hierzu nahmen mit zunehmender Jahreszeit ab, während der Beitrag von Senf (mit kleineren Pollenkörnern) zunahm (Tab. II, Abb. 1) Basierend auf diesen Schätzungen, sowie auf veröffentlichten Werten zum Nährwert der entsprechenden Pollen sieht es so aus, als ob die Bienen den Pollentyp erst spät in der Saison wechselten. Offensichtlich kompensierte der höhere Protein- und Lipidanteil des neuen dominanten Pollentyps (Senf) nicht die kleineren eingetragenen Pollenladungen (Abb. 5)

Der Pollentyp und die Diversität der Pollenladungen variierte nicht in Abhängigkeit von der Körpergrösse der Bienen. Wir fanden jedoch eine signifikante Beziehung zwischen der Größe der Weibchen und der Größe der grössten eingetragenen Ladungen. Entgegen der Erwartungen waren es die Bienen mittlerer Größe, die die größten Pollenladungen trugen, sowohl im Hinblick auf Pollenzahlen als auch Volumen (Abb. 4). Diese Beziehung ist interessant und sollte näher untersucht werden.
Megachile rotundata / Alfalfa / Zusammensetzung der Pollenladungen / jahreszeitliche Schwankung / Körpergröße

\section{REFERENCES}

Beil M., Horn H., Schwabe A. (2008) Analysis of pollen loads in a wild bee community (Hymenoptera: Apidae) - a method for elucidating habitat use and foraging distances, Apidologie, $39,456-467$.

Cane J.H., Sipes S. (2006) Characterizing floral specialization in bees: analytical methods and a revised lexicon for oligolecty, in: Wasser N.M., Ollerton J. (Eds.), Plant-pollinator interactions: from generalization to specialization, University of Chicago Press, Chicago, pp. 99-122.

Coelho J. (1997) Sexual size dimorphism and flight behavior in cicada killers (Sphecius speciosus), Oikos, 79, 371-375.

Feurbacher E., Fewell J.H., Roberts S.P., Smith E.F., Harrison J.F. (2003) Effects of load type (pollen or nectar) and load mass on hovering metabolic rate and mechanical power output in the honey bee Apis mellifera, J. Exp. Biol. 206, 1855-1865.

Horne M. (1995) Pollen preference and its relationship to nesting success of Megachile rotundata, Ann. Entomol. Soc. Am. 88, 862-867.

Jensen P.D, O’Neill K.M., Lavin M. (2003) Pollen provision records for three species of solitary bees (Hymenoptera: Megachilidae; Megachile, Heriades) in southwestern Montana, Proc. Entomol. Soc. Wash. 105, 196-203.

Kapp R.O., Davis O.K., King J.E. . (2000) Pollen and Spores (second edition), American Association of Stratigraphic Palynologists Foundation, College Station, Texas.

Karise R., Mänd M., Ivask M., Koskor E., Bender A. (2006) The effect of pollen amount and its caloric value in hybrid lucerne (Medicago $\times$ varia) on its attractiveness to bumble bees, Agron. Res. 4, 211216.

Klostermeyer E.C., Mech Jr. S.J., Rasmussen W.B. (1973) Sex and weight of Megachile rotundata (Hymenoptera: Megachilidae) progeny associated with provision weights, J. Kans. Entomol. Soc. 46, 536-548.

Ludwig J.A., Reynolds J.F. (1988) Statistical Ecology, J. Wiley and Sons, New York.

McGregor S.E. (1976) Insect pollination of cultivated crops, Agriculture Handbook No. 496, USDA Agricultural Research Service, Washington, DC.

Müller A, Diener S., Schnyder S., Stutz K., Sedivy C., Dorn S. (2006) Quantitative pollen requirements of solitary bees: implications for bee conservation and the evolution of bee-flower relationships, Biol. Conserv. 130, 604-615. 
Ne'eman G.A., Dafni A., Potts S.G. (1999) A new pollination probability index (PPI) for pollen load analysis as a measure for pollination effectiveness of bee, J. Apic. Res., 38, 19-23.

Neff J.L. (2008) Components of nest provisioning behavior in solitary bees (Hymenoptera: Apoidea), Apidologie, 39, 30-45.

O'Neill K.M. (2001) Solitary wasps: behavior and natural history, Cornell University Press, Ithaca, New York.

O’Neill K.M., O'Neill R.P., Blodgett S., Fultz J.E. (2004) Variation in Megachile rotundata pollen load composition in relation to flower diversity (Hymenoptera: Megachilidae), J. Kans. Entomol. Soc. 77, 619-625.

O’Rourke M.K., Buchmann S.L. (1991) Standardized analytical techniques for bee-collected pollen, Environ. Entomol. 20, 507-513.

Pitts-Singer T.L. (2008) Past and present management of alfalfa bees, in James R., PittsSinger T.L. (Eds.), Bee Pollination in Agricultural Ecosystems, Oxford University Press, New York, pp. $105-123$.
Roulston T.H., Cane J.H. (2000) What governs protein content of pollen: pollinator preferences, pollenpistil interactions, or phylogeny? Ecol. Monogr. 70, 617-643.

Roulston T.H., Cane J.H. (2002) Pollen nutritional content and digestibility for animals, Plant. Syst. Evol. 222, 187-209.

Shreeves G., Field J. (2008) Parental care and sexual sixe dimorphism in wasps and bees, Behav. Ecol. Sociobiol. 62, 843-852.

Small E., Brooks B., Lefkovich L.P., Fairey D.T. (1997) A preliminary analysis of the floral preference of the alfalfa leafcutting bee, Can. Field-Nat. 111, 445-453.

Stace P. (1996) Protein content and amino acid profiles of honeybee-collected pollens. Bee ' $\mathrm{N}$ Trees Consultants, Lismore, NSW Australia, http:// www.honeybee.com.au/Library/Pollenindex. html, accessed 12 December 2009.

Strickler K., Freitas S. (1999) Interactions between floral resources and bees (Hymenoptera: Megachilidae) in commercial alfalfa seed fields, Environ. Entomol. 28, 178-187. 